In addition to a love of fine food and travel, Oberling was passionate about twentieth-century classical music, counting among his favorite composers Philip Glass and Havergal Brian. He was also a lifelong poet, publishing a compendium of his early poetry as Journeys to the Sea of Zanj: Poems 1947-1971 in 1971. In his later years, his poetry was published in the journal Orbis. In 2007, he completed the poem "Three Images":

As lightly as snow

whirls among the trees, dead leaves fall, barely touching the earth.

It is October still, yet already winter writes its hieroglyphics of frost upon my window panes.

In a bleak, empty field crows bursting into flight

rip the air with their razor-sharp wings.

Oberling is survived by his wife Patricia Oberling and his brother JeanJacques Oberling, as well as his first wife Geraldine Oberling, their two children, Nicholas Oberling and Ariane Pinson, and three grandchildren. $\nsim$

Ariane Pinson U.S. Army Corp of Engineers, Albuquerque District

\title{
Rita G. Sabat
}

1974-2013

RITA G. SABAT, ASSISTANT PROFESSOR OF INTERNATIONAL AFFAIRS AT THE Faculty of Law and Political Sciences, Notre Dame University-Louaizé, Lebanon, passed away peacefully on 29 December 2013 after a long battle with breast cancer. Sabat was born in March of 1974 in Lebanon to (Amin) George Sabat and Yolande Saber. She studied in Lebanon, Cyprus, and the U.S., and received a $\mathrm{PhD}$ in international affairs from Florida International University (2010). 
Since her appointment at Notre Dame University, Lebanon, she taught courses in the areas of international institutions, gender, non-governmental organizations, and development. As the only female professor to date, she played an important role in developing both gender balance and a gendered approach to teaching in the Department of Government and International Relations at NDU. Sabat conducted extensive field research on the women's movement in Lebanon in the areas of human rights and peace and security, and on the use of the arts in peace building for the Peace-Building Academy. She assisted in the design of research methodologies for several projects and proposals, including one on women-owned business, discrimination, and corruption, and on conflict resolution through community-level case studies in Tripoli and Baalbek.

Sabat served as a member of the Regional Network on Women, Peace, and Security, which aims at developing policies in the MENA region according to UNSC Resolution 1325; was a member the Technical Task-Force of the National Gender-Based Violence Unit, which is headed by the Lebanese Ministry of Social Affairs and Lebanese-based NGOs; and was an advisory board member for Abaad Resource Center for Gender Equality. She was also a senior consultant to the Lebanese Development Network (LDN) and its Carthage Center for Research and Information (CCRI), where she served as a gender and human rights specialist. Between 2012 and 2013, despite her illness, she presented her research on gender equality, women's nongovernmental organizations, violence against women, and gendered human security in Lebanon at international conferences in Switzerland, the U.S., India, and the Emirates. With LDN/CCRI she fulfilled her role as a gender expert for a Swiss labor policy project in five MENA countries (Lebanon, Jordan, Kuwait, Qatar, and the EUA) and served in the same capacity for an International Labor Organization (ILO) project assessing the employability of the Syrian refugees in Lebanon. Recently Sabat published a chapter entitled, "Translating International Gender Equality Norms: The Case of Combating Violence against Women in Lebanon," in Feminist Strategies in International Governance, edited by Elisabeth Prügl, Güelay Cagler, and Suzanne Swindle (Routledge 2012). She also guest edited an issue of Al-Raida on "Gender-Based Violence in the Arab World."

Not long before she passed away, she spoke at a panel organized jointly by the Community Service Office (CSO) and the Human Rights Club (HRC) at NDU on the role of religion in stopping gender discrimination. She also spoke at another event in New York co-hosted by the International Civil Society Action Network (ICAN), the International Peace Institute (IPI), and the Norwegian 
Mission to the UN, where she focused on the connection between genderbased violence in Lebanon and international insecurity.

The news of Sabat's passing fell hard on her family, friends, colleagues, and students, who used social media extensively to mourn her and express their sorrow. There isn't enough space in this obituary to share all that has been written, and continues to be written, on her Facebook timeline, where she is most remembered as genuine, passionate, giving, caring, committed, selfless, humble, enduring, spiritual, joyful, humorous, a good friend, a good teacher, and an excellent listener.

According to a friend, who spoke to her four weeks before she left this world, Sabat stated she knew God's will and was ready to accept it. All of those who knew her through this, and other ordeals, testified to her brave, gracious, and collected manner in dealing with life's challenges. Another friend also stated that prior to her departure, though breathless from failing lungs, she spoke with deep passion and concern about the career of a friend/colleague of hers. It is not surprising that the posts bestowed upon her the above-mentioned attributes, for according to one of her students, Sabat's favorite quote was, "Work for a cause, not for applause; live life to express, not to impress; don't strive to make your presence noticed, just make your absence felt." Her absence will surely be missed.

With Sabat's passing, the gender equality and human rights movement in the Middle East in general, and Lebanon in particular, loses a promising scholar and a staunch activist. A group of friends, students, and colleagues both in Lebanon, Switzerland, and the U.S. are in the process of establishing an endowment in her name that will help carry on a cause most dear to her, namely, that "women's rights should be a foreign policy priority."

Sabat is survived by her daughter Samira Haymen, her husband Jad FadelHassan, her father George, her mother Yolande Saber, and her brothers Toni and Gilbert and their families. $\%$

Guita Hourani

Notre Dame University, Lebanon 